\section{Sumbangsih, Volume (2), 2021, 8-14 \\ Jurnal Sumbangsih}

https://sumbangsih.Ippm.unila.ac.id/index.php/jsh/index $\therefore 0 \%$ \%

涪(i)i)

SUMBANGSIH

\title{
Capacity Building Pemahaman Tentang Asean Economic Community (AEC) di MAN 1 Bandar Lampung dalam Menyongsong Indonesia Emas 2045
}

\author{
Desy Churul Aini ${ }^{*}$, Siti Azizah¹ \\ ${ }^{1}$ Fakultas Hukum, Universitas Lampung, Bandar Lampung, 35145, Lampung, Indonesia
}

\begin{abstract}
Abstrak.
Era Globalisasi saat sekarang ini telah menjadi kenyataan yang menyatukan seluruh negara di dunia ini melalui aktifitas ekonomi, ilmu pengetahauan dan teknologi, politik, dan sosial budaya. Salah satu dampak globalisasi adalah munculnya Regional Economic Integration diberbagai belahan dunia ini salah satunya adalah Masyarakat Ekonomi ASEAN (MEA). Kelanjutan komitmen seluruh negara ASEAN setelah memasuki MEA 2015 adalah MEA 2025. Cetak biru 2025 bertujuan meningkatkan kualitas integrasi dan pertumbuhan ekonomi di kawasan. Peningkatan integrasi ini akan dilakukan melalui lima Pilar MEA 2025 yaitu (1) Ekonomi ASEAN yang terintegrasi dan kohesif; (2) ASEAN yang kompetitif dan dinamis; (3) peningkatan konektivitas dan kerja sama sektoral; (4) ASEAN yang tangguh, inklusif, dan berorientasi serta fokus ke masyarakat; serta (5) ASEAN Global. Hal yang sungguh memprihatinkan adalah persoalan sosialisasi dan edukasi yang kurang gencar sehingga para stakeholders atau pemangku kepentingan banyak yang tidak mengetahui secara jelas berbagai skim perdagangan bebas tersebut. Sehingga, dengan demikian tidak ada persiapan matang menghadapi kompetisi bebas dalam MEA itu. Baru menjelang saat dilaksanakan kita kerja keras menyiapkan diri, sementara sebagian pesaing kita sudah jauh didepan dengan berbagai strategi untuk memenangkan atau mendapatkan keuntungan terbesar dari keterbukaan atau integrasi ekonomi yang terjadi. Capacity Building tentang Pemahaman Asean Economic Community (AEC) atau Masyarakat Ekonomi Asean kepada siswa-siswi Madrasah Aliyah Negeri (MAN) 1 Bandar Lampung adalah judul pelaksanaan penyuluhan tentang Capacity Building Asean Economic Community (AEC) dalam menyongsong Indonesia Emas 2045 di Madrasah Aliyah Negeri 1 Bandar Lampung, yang diselenggarakan pada hari Sabtu, tanggal 29 Agustus 2020 dapat disimpulkan sebagai berikut; Tingkat pengetahuan dan pemahaman siswa-siswi di Madrasah Aliyah Negeri 1 Bandar Lampung tentang Asean Economic Community (AEC) dalam menyongsong Indonesia Emas 2045 sebelum dilakukan sosialisasi masih rendah. Hal ini tercermin dari pertanyaan-pertanyaan yang diajukan kepada narasumber dari peserta penyuluhan. Pengetahuan dan pemahaman peserta penyuluhan tentang konsep Asean Economic Community (AEC) sebagai Upaya menyongsong Indonesia Emas 2045, sesudah penyuluhan meningkat. Indikator kesimpulan ini didapat dari terjawabnya dengan baik pertanyaan-pertanyaan yang diajukan oleh narasumber kepada para peserta sekitar masalah konsep Asean Economic Community (AEC).
\end{abstract}

*Corresponding author: desy.churulaini@fh.unila.ac.id

Received 05 October 2021; Received in revised form 19 October 2021; Accepted 19 October 2021

Available online 27 December 2021

Lembaga Penelitian dan Pengabdian Kepada Masyarakat

Universitas Lampung 
Kata kunci.

Hak Kekayaan Intelektual, Hak Kekayaan Intelektual Komunal, Hak Cipta

\section{PENDAHULUAN}

Kita semua menyadari bahwa zaman terus berubah dengan karakteristik masing-masing. Setiap era memiliki karakteristiknya masing-masing dan kalau kita cermati dengan seksama, perubahan (revolusi) terjadi dalam kurun yang semakin pendek. Dari ribuan tahun, menjadi ratusan tahun dan kini menjadi kurang dari sepuluh tahunan. Hal ini dikarenakan semakin tinggi dan besarnya modal manusia, ilmu pengetahuan, teknologi dan inovasi. Tentu ini semua, membawa konsekuensi terhadap semakin kompleksnya (sofistikasi) persoalan yang harus kita hadapi dan semuanya harus diselesaikan dalam waktu yang lebih singkat. Hal ini diperkuat dengan hasil survei yang telah dilakukan oleh Price Water Coopers (PwC) terhadap 2.106 eksekutif senior dunia yang hasilnya dirilis juli 2016. Hasil survei tersebut sejalan dengan kajian yang telah dilakukan oleh Yves Morieux [1].

Era Globalisasi saat sekarang ini telah menjadi kenyataan yang menyatukan seluruh negara di dunia ini melalui aktifitas ekonomi, ilmu pengetahauan dan teknologi, politik, dan sosial budaya. Dunia seakan menjadi sebuah negara besar saja tanpa batas, sehingga setiap orang memiliki "kebebasan" untuk boleh pergi kemana saja. Salah satu dampak globalisasi adalah munculnya Regional Economic Integration diberbagai belahan dunia ini. Association of South East Asian Nations atau disingkat ASEAN salah satunya, sebagai kekuatan ekonomi kawasan di Asia, disamping kawasan ekonomi lainnya seperti EU (EFTA), NAFTA, APEC, SAARC, dan sebagainya [2].

Asean menyepakati untuk mengembangkan suatu kawasan yang terintegrasi dengan membentuk suatu komunitas negara-negara Asia Tenggara yang terbuka, damai, stabil dan sejahtera, saling peduli, diikat bersama dalam kemitraan yang dinamis di tahun 2020. Harapan tersebut dituangkan dalam visi Asean 2020 di Kuala Lumpur tahun 1997. Visi Asean ini, yaitu terdiri atas keinginan untuk membentuk Komunitas Asean yang terdiri dari 3 pilar utama, yaitu [3];

\section{a. Komunitas politik-keamanan Asean (Asean Political-security Community/APSC) \\ b. Komunitas Ekonomi Asean (Asean economic community/AEC) \\ c. Komunitas Sosial budaya (Asean Sosio-cultural Community/ASCC)}

Ketiga pilar tersebut saling berkaitan satu sama lain dan saling memperkuat tujuan pencapaian perdamaian yang berkelanjutan, stabilitas serta pemerataan kesejahteraan di kawasan. Konsep pelaksanaan dalam enam tahun pertama dipandu dengan Hanoi Plan of action (HPA) yang dikeluarkan pada 1998. Kemudian tahap selanjutnya adalah berlangsungnya KTT (Konferensi Tingkat Tinggi) Asean yang ke-10 di Vientiane, Laos tahun 2004, konsep komunitas Asean ini kemudian mengalami kemajuan dengan disetujuinya tiga rencana aksi Plan of Action/ (PoA) untuk masing-masing pilar yang merupakan program jangka panjang untuk merealisasikan konsep komunitas ASEAN [4].

Perkembangan realisasi konsep MEA (Masyarakat ekonomi Asean) selanjutnya, dirumuskan tujuan akhir integrasi ekonomi, yakni mewujudkan Asean Vision 2020 pada deklarasi Bali Concord II, Oktober 2003. Pencapaian dilakukan melalui lima pilar, yaitu; aliran bebas barang dan jasa, investasi, tenaga kerja terampil, dan aliran modal yang lebih bebas. Berbagai kerjasama ekonomi dilakukan khususnya di bidang perdagangan dan investasi, dimulai dari Preferential Trade Arragement (PTA, 1977), Asean Free Trade Area 
(AFTA,1992), Asean Framework Agreement on services (AFAS, 1995) dan Asean Investment Area (AIA, 1998), kemudian dilengkapi dengan perumusan sektor prioritas integrasi dan kerjasama di bidang moneter lain [3].

Pencapaian MEA memerlukan implementasi langkah-langkah liberalisasi dan kerjasama, termasuk peningkatan kerjasama dan integrasi di area-area baru antara lain; pengembangan sumber daya manusia dan peningkatan kapasitas (capacity building); konsultasi yang lebih erat di kebijakan makro ekonomi dan keuangan; kebijakan pembiayaan perdagangan; peningkatan infrastruktur dan hubungan komunikasi; pengembangan transaksi elektronik melalui e-Asean; integrasi industri untuk meningkatkan sumber daya regional; serta peningkatan keterlibatan sektor swasta [3].

Berdasarkan pemarapan di atas dapat kita proyeksikan bahwa generasi bangsa yang sekarang ini sedang bersekolah atau kuliah akan menghadapi persoalan yang semakin kompleks dan harus diselesaikan dalam waktu yang lebih singkat. Ini yang menjadi salah satu fokus obyektif dunia pendidikan diabad 21. Bekal yang kita berikan harus mencerminkan kemampuan (kompetensi) untuk menyelesaikan kompleksitas persoalan, sangat dimungkinkan dunia pendidikan akan terjebak sebagai mesin pencipta generasi kedaluwarsa (expired generation). Karena, kompetensi yang dimiliki tidak sesuai (disconnected) dengan persoalan yang dihadapi. Menghadapi tantangan seperti ini, tidak ada cara lain yang paling ampuh kecuali menyiapkan generasi yang memiliki keutuhan kompetensi sikap (attitude), ketrampilan (skills) dan pengetahuan (knowledge) [1].

Hasil survey yang dilakukan di lima kota besar, yaitu Jakarta, Surabaya, Medan, Makasar dan Pontianak, menunjukkan bawa pemangku kepentingan baik pemerintah pusat dan daerah, akademisi, maupun masyarakat masih rendah pemahamannya dan pengetahuannya terhadap MEA. Ini tentu sebuah ironis, karena negara-negara lain di Asean sudah secara intens menyiapkan diri menyongsong MEA sementara Indonesia malah sebagian besar rakyatnya belum mengetahui apa itu MEA [2].

Bahkan hal sungguh memprihatinkan adalah sosialisasi dan edukasi yang kurang gencar sehingga para stakeholders atau pemangkku kepentingan banyak yang tidak mengetahui secara jelas berbagai skim perrdagangan bebas tersebut. Sehingga, dengan demikian tidak ada persiapan matang menghadapi kompetisi bebas dalam MEA itu. Baru menjelang saat dilaksanakan kita kerja keras menyiapkan diri, sementara sebagian pesaing kita sudah jauh didepan dengan berbagi strategi untuk memenangkan atau mendapatkan keuntungan terbesar dari keterbukaan atau integrasi ekonomi yang terjadi.Kenyataan-kenyataan ini sebagai gambaran buruknya sistem manajemen pembangunan yang diterapkan di Indonesia. Sistem perencanaan, pengoranisasian, pelaksanaan dan pengendalian tidak berorientasi kepada future management, miskin dalam inovasi dan lambat dalam melakukan perubahan untuk menyesuaikan diri dengan perubahan yang terus terjadi. Akibatnya adalah Indonesia selalu tertinggal jauh kebelakang di bandingkan dengan negara-negara lainnya [2].

Berdasarkan uraian tersebut penulis tertarik untuk melakukan Capacity Building tentang Pemahaman Asean Economic Community (AEC) atau Masyarakat Ekonomi Asean kepada siswa-siswi Madrasah Aliyah Negeri 1 Bandar Lampung sehingga mereka mampu mempersiapkan diri dengan sebaik-baiknya dalam menghadapi tantangan globalisasi.

Berdasarkan uraian diatas maka dalam kegiatan Capacity Building ini masalah yang akan diangkat adalah: masih belum tersosialisasinya pengetahuan dan pemahaman mengenai Asean Economic Community (AEC) atau Masyarakat Ekonomi Asean kepada siswa-siswi Madrasah Aliyah Negeri 1 Bandar Lampung. 


\section{METODE}

\section{Pelaksanaan}

Untuk meningkatkan pengetahuan para siswa/i di MAN 1 terhadap arti pentingnya memberikan pemahaman tentang pengetahuan Asean Economic Community (AEC) atau Masyarakat Ekonomi Asean di lingkungan sekolah yang merupakan institusi formal pendidikan diperlukan kegiatan pengabdian kepada masyarakat dalam bentuk Capacity Building Pemahaman tentang Asean Economic Community (AEC) di MAN 1 Bandar Lampung dalam menyongsong Indonesia Emas 2045. Pelaksanaan kegiatan pengabdian masyarakat dilaksanakan pada:

Tempat : MAN 1 Bandar Lampung

Narasumber : Tim Penyuluh Pengabdian Dosen Fakultas Hukum Unila

Peserta : : Siswa/i MAN 1 Bandar Lampung

\section{Metode pengabdian}

Metode yang dipergunakan dalam pelaksanaan pengabdian kepada masyarakat dan relevan dengan Capacity Building Pemahaman tentang Asean Economic Community (AEC) di MAN 1 Bandar Lampung dalam menyongsong Indonesia Emas 2045 adalah:

a. Tim menyampaikan materi pengertian Pemahaman tentang Asean Economic Community (AEC) dengan memanfaatkan teknologi komputer (laptop) dan jaringan internet yang tersedia.

b. Diskusi dan tanya jawab terkait dengan bentuk-bentuk kerjasama internasional, tantangan, hambatan dan peluang diera perdagangan bebas Asean Economic Community (AEC) dalam menyongsong Indonesia Emas 2045.

\section{HASIL DAN PELAKSANAAN}

\section{Pendahuluan}

Sebagaimana program kegiatan Capacity Building Pemahaman tentang Asean Economic Community (AEC) dalam menyongsong Indonesia Emas 2045 di MAN 1 Bandar Lampung, mulai dari tahap perencanaan, Proses Pelaksanaan dan hasil akhir kegiatan itu, dilaporkan sebagai berikut:

\section{Perencanaan}

Kegiatan penyuluhan Capacity Building Pemahaman tentang Asean Economic Community (AEC) dalam menyongsong Indonesia Emas 2045 di MAN 1 Bandar Lampung sesuai yang direncanakan dalam program jurusan bagian Hukum Internasional Fakultas Hukum Unila, dapat berjalan dengan baik.

Sebelum dilakukan kegiatan sosialisasi, Tim Pengabdian Jurusan Hukum Internasional Fakultas Hukum UNILA, terlebih dahulu melakukan survei lokasi dan menghubungi pihak sekolah, yang dalam hal ini tim dari FH berhubungan dengan Bapak Drs. Husnul Khaitami selaku Waka Humas MAN 1 Bandar Lampung dan Ibu Hera Suzana, S.Pd. yang ditunjuk oleh Bapak Husnul untuk membantu secara teknis proses pelaksanaan kegiatan penyuluhan ini. Hasil dari survei lapangan tersebut tim kami sudah mendapat gambaran kondisi MAN 1 yang meniadakan proses belajar mengajar untuk tatap muka karena 
pendemi covid-19.

Beberapa waktu kemudian karena situasi penanganan pendemi Covid-19 masih harus melakukan kegiatan belajar mengajar secara daring, maka pihak sekolah dan tim penyuluh sepakat untuk melaksanakan kegiatan melalui cara daring dengan aplikasi zoom meeting. Kemudian diadakan negosiasi dan kesepakatan bersama untuk menentukan waktu, tempat dan pendanaan dari pelaksanaan kegiatan ini.

Pada saat akan dilakukan Penyuluhan, terlebih dahulu dilakukan wawancara dan perbincangan kepada para guru untuk lebih meyakinkan Tim Pengabdian Unila terhadap gambaran, kemampuan serta pengetahuan dasar kelompok sasaran dalam pemahaman tentang wawasan peserta anak didik tentang Asean Economic Community (AEC) dan bagaimanakah pengenalan siswa/siswi MAN 1 tentang bahasan tersebut apakah ada dalam kurikulum pelajaran. Berdasarkan hasil wawancara dan perbincangan sebagian besar kelompok sasaran tidak dapat menjawab pertanyaan Tim Pengabdian dan menyatakan bahwa sebelumnya mereka belum mendapatkan materi itu.

Berdasarkan gambaran diatas, secara menyeluruh dapat dikatakan bahwa kemampuan dasar calon peserta penyuluhan ini tentang konsep Asean Economic Community (AEC) masih rendah. Kondisi ini dapat dimaklumi karena para peserta belum pernah mendapatkan pengetahuan dan pemahaman serta penyuluhan tentang konsep Asean Economic Community (AEC).

\section{Pelaksanaan}

Salah satu proses yang dapat dilakukan untuk meningkatkan pengetahuan masyarakat adalah melalui penyuluhan. Metode penyuluhan dilakukan untuk mentransfer pengetahuan dan informasi yang tepat kepada masyarakat sehingga diharapkan dapat terjadi peningkatan pengetahuan tentang konsep Asean Economic Community (AEC) dalam menyongsong Indonesia Emas 2045.

Berkenaan dengan hal tersebut, maka melalui kegiatan ini dilakukan penyuluhan tentang hal-hal yang berhubungan dengan konsep Asean Economic Community (AEC) dalam menyongsong Indonesia Emas 2045, yang bertempat di Madrasah Aliyah Negeri 1 (MAN 1) Bandar Lampung yang dilaksanakan pada tanggal 29 Agustus 2020, yang diikuti oleh 36 (tiga puluh enam) siswa dan siswi dan beberapa guru MAN 1 Bandar Lampung. Kegiatan zoom meeting ini pada saat pelaksanaan meminta kepada para peserta untuk mengisi link online daftar hadir peserta disertai dengan saran dan manfaat yang mereka dapatkan dari kegiatan ini. Diharapkan dengan penyuluhan tersebut, mereka mendapatkan pengetahuan dan informasi yang menjadi bekal bagi mereka untuk mengenal tentang bagaimana konsep Asean Economic Community (AEC) dalam menyongsong Indonesia Emas 2045 untuk membangun sumber daya manusia yang siap berkompetisi di era globalisasi.

Narasumber penyuluhan merupakan praktisi akademisi yang berasal dari Bagian Hukum Internasional Fakultas Hukum UNILA yang menguasai persoalan di bidangnya. Adapun materi yang disampaikan oleh narasumber adalah sebagai berikut:

Tabel 1. Pembagian Materi

\begin{tabular}{clll}
\hline NO & \multicolumn{1}{c}{ M A T E R I } & NARA SUMBER & KEPAKARAN \\
\hline 1. & Gambaran Umum Asean & Siti Azizah & Ilmu Hukum \\
2. $\begin{array}{l}\text { Bentuk kerjasama internasional, tantangan, hambatan dan } \\
\text { peluang di era perdagangan bebas Asean Economic } \\
\text { Community (AEC) dalam menyongsong Indonesia Emas 2045 }\end{array}$ & Desy Churul Aini & Ilmu Hukum \\
\hline
\end{tabular}


Kegiatan penyuluhan meskipun berjalan melalui daring berjalan dengan tertib dan lancar, terlihat dari antusias para siswa dan siswi MAN 1 Bandar Lampung dalam diskusi dan Tanya jawab. Beberapa permasalahan yang menyangkut persoalan konsep Asean Economic Community (AEC) ini pun dibahas, mereka memberikan pertanyaan-pertanyaan yang kritis tentang materi ini. Para siswa dan siswi cukup antusias memberikan contoh-contoh yang diminta oleh narasumber berkaitan dengan apa yang menjadi fokus pembanguan ekonomi Indonesia dalam menghadapi persaingan global. Banyak jenis-jenis profesi baru muncul yang kemudian jadi bahasan diskusi ditengah merosotnya perekonomian negara karena pendemi covid-19.

\section{Faktor Pendukung dan Penghambat}

\section{Faktor Pendukung}

Faktor pendukung kegiatan penyuluhan ini dapat dilaksanakan dengan baik karena didukung oleh faktor-faktor sebagai berikut:

a. Apresiasi, kemauan, minat dan perhatian yang cukup besar dari peserta dan Tim baik sebelum, maupun sesudah penyuluhan.

b. Rasa ingin tahu peserta sangat besar mengenai tema sosialisasi konsep Asean Economic Community (AEC).

c. Kesungguhan dan motivasi para peserta baik guru maupun murid karena didukung oleh para guru Madrasah Aliyah Negeri 1 Bandar Lampung.

d. Peserta bersedia meluangkan waktu sepenuhnya, karena keingintahuan mereka tinggi.

e. Dukungan dari Tim Pengabdian dari Fakultas Hukum UNILA, yang memiliki pengetahuan, kemampuan dalam penyuluhan hukum tentang masalah hukum ekonomi internasional.

f. Bantuan tehnis dan kepercayaan dari pihak Madrasah Aliyah Negeri 1 Bandar Lampung untuk melaksanakan penyuluhan dan pembinaan.

Faktor Penghambat

Terdapat beberapa hambatan yang dihadapi dalam kegiatan penyuluhan diantaranya sebagai berikut:

a. Terbatasnya ruang dan waktu karena kendala kuota sehingga bimbingan dan penyuluhan yang diberikan kurang maksimal karena dilakukan dengan zoom meeting.

b. Terkendala masalah-masalah tehnis dari peserta dan narasumber yang juga "gagap" teknologi, kendala sinyal yang "naik dan turun" sehingga proses komunikasi kadangkadang terhambat.

c. Diskusi menjadi kurang interaktif karena banyaknya polusi suara yang berasal dari para peserta, sehingga peserta di "mute" (bisukan) oleh host dan diskusi tanya jawab dilakukan melalui kolom chat.

\section{KESIMPULAN}

Pelaksanaan Penyuluhan tentang Capacity Building Asean Economic Community (AEC) dalam menyongsong Indonesia Emas 2045 di Madrasah Aliyah Negeri 1 Bandar Lampung, yang diselenggarakan pada hari Sabtu, tanggal 29 Agustus 2020 dapat disimpulkan sebagai 
berikut;

a. Tingkat pengetahuan dan pemahaman siswa-siswi di Madrasah Aliyah Negeri 1 Bandar Lampung tentang Asean Economic Community (AEC) dalam menyongsong Indonesia Emas 2045 sebelum dilakukan sosialisasi masih rendah. Hal ini tercermin dari pertanyaan-pertanyaan yang diajukan kepada narasumber dari peserta penyuluhan di Madrasah Aliyah Negeri 1 Bandar Lampung sebelum materi penyuluhan diberikan, dimana sebelum materi diberikan peserta belum memahami konsep Asean Economic Community (AEC) sebagai Upaya menyongsong Indonesia Emas 2045.

b. Pengetahuan dan pemahaman peserta penyuluhan tentang konsep Asean Economic Community (AEC) sebagai Upaya menyongsong Indonesia Emas 2045, sesudah penyuluhan meningkat. Indikator kesimpulan ini didapat dari terjawabnya dengan baik pertanyaan-pertanyaan yang diajukan oleh narasumber kepada para peserta sekitar masalah konsep Asean Economic Community (AEC).

\section{UCAPAN TERIMA KASIH}

Terima kasih disampaikan kepada LPPM Unila yang telah mendanai kegiatan Pengabdian Kepada Masyakarat ini sehingga dapat dilakukan dengan baik atas hibah dan Pengabdian Pemula Dipa BLU Unila tahun 2020.

\section{DAFTAR PUSTAKA}

[1] https://www.uny.ac.id/fokus-kita/prof-dr-ir-kh-mohammad-nuh-dea.

[2] https://www.kompasiana.com/yupiter/5ad7ed83dd0fa83e976b9503/indonesia-dan-mea?page=all.

[3] Direktorat kerjasama ASEAN. (2008). Kenali ASEAN Kita. Jakarta: Kementerian Luar Negeri RI. 